\title{
THE RELATIONSHIP OF LEARNING DISCIPLINE, PARENTAL ATTENTION, AND LEARNING MOTIVATION WITH MATHEMATICS LEARNING OUTCOMES OF STUDENTS IN VIII CLASS OF MTS NEGERI SUMBERAGUNG BANTUL
}

\author{
Choirunisa Desi Milasari Pa, Sumargiyani ${ }^{b}$ \\ Mathematics Education Study Program of FKIP UAD \\ Jln. Ringroad Selatan, Tamanan, Banguntapan, Bantul, Yogyakarta \\ achoirunisadesi194@gmail.com, ${ }^{b}$ sumargiyani@pmat.uad.ac.id
}

\begin{abstract}
Result of low mathematics learning associated with many factors. relationship of learning discipline, parental attention, and learning motivation are some of the factors related to the learning outcomes. Therefore, this study was conducted in order to determine whether or not a positive and significant between the relationship of learning discipline, parental attention, and learning motivation with mathematics learning outcomes of students in the VIII class of MTs Negeri Sumberagung Bantul in the even semester in Academic Year of 2015/2016. The population of this research was all students of class VIII MTs Negeri Sumberagung Bantul in the even semester of the academic year 2015/2016 consisting of 5 classes with the total number of 153 students. As a sample class was class VIII B consisting of 30 students by random sampling technique to the class. The data collection technique was performed by a method of testing and questionnaires. The test method used collection data on mathematics learning outcomes of students, whereas the questionnaire method used collection data learning discipline, parental attention, and learning motivation. Test data analysis requirements using the test for normality, independent, and the test for linearity. Data analysis for hypothesis testing using correlation analysis and linear regression analysis. The research result showed that there was a significant positive correlation between learning discipline, parental attention, and learning motivation with $\mathrm{F}_{\text {count }}=11,58570847$ and $\mathrm{F}_{\text {table }}=2,98$ in order to obtain $\mathrm{F}_{\text {count }}>\mathrm{F}_{\text {table. }}$. Multiple correlation coefficient (R) of 0,7563508799 with a regression equation $\hat{Y}=-177,183+1,348 X_{1}+0,560 X_{2}+0,164 X_{3}$

with a coefficient of determination was $\left(\mathrm{R}^{2}\right) 0,5720666536$ and effective contribution $\mathrm{X}_{1}=18,786 \%$, $\mathrm{X}_{2}=15,582 \%$ and $\mathrm{X}_{3}=6,216 \%$.
\end{abstract}

Keywords: learning discipline, parental attention, learning motivation, mathematics learning result

\section{INTRODUCTION}

Education is a means that plays an important role in the progress of the nation and state. The development of science and technology is inseparable from the underlying sciences, one of which is mathematics. Mathematics is the science of logic regarding shapes, structures, quantities and concepts that relate to one another with large numbers divided into three fields, namely algebra, analysis, and geometry (James and James in Erman Suherman, et al, 2003: 16-17). In general, the assumption that mathematics is always associated with something difficult and abstract. As a result of mathematics is one of the fields that is generally considered to be the most difficult and boring for students. Based on the data of the Final Semester Examination (FSE) obtained from the eighth-grade mathematics teacher of MTs Negeri Sumberagung, Bantul Regency, it is known that out of 153 students most of the students have not reached the Minimum Completion Criteria (MCC) of 75 in Mathematics applied at school. This shows that the mathematics learning outcomes of students are not maximal or still low.

Of the many influential factors, there are several factors that influence the learning outcomes of class VIII students of MTs N Sumberagung Bantul, namely the discipline of learning, parental attention, and motivation to learn. Discipline is an attitude that affects students in learning if a student does not have a disciplined attitude that will cause less responsibility for learning (Slameto, 2013: 67). Based on the results of observations conducted in July - September 2015 it was found that the lack of discipline in 
student learning. This is seen when the teacher is explaining the students' learning material is crowded themselves so that the student learning process is disrupted and results in student learning outcomes.

In addition, it also found a lack of learning motivation in students. Motivation is a change of energy in a person that is characterized by an effective push and reaction - the reaction reaches the goal, (Frederick J. McDonald in Wasty Soemanto, 2012: 205). Some students are lazy to record material and students tend to stop working on the problem when the question is considered difficult so that it can have an impact on student learning outcomes. Based on the results of interviews on October 21, 2015, information was obtained from several class VIII students of MTs Negeri Sumberagung, Bantul Regency, that they considered mathematics to be a difficult subject. In addition, information is also obtained that parents do not accompany children when learning. Attention is the concentration or concentration of all individual activities aimed at an object or set of objects (Ben Walgito, 2010: 110). Whereas parents are biological mothers, parents who are considered old (clever, experts and so on), respected people in the village (Syaiful Bahri Djamarah, 2014: 51). The purpose of this study is to find out whether or not there are:

1. Relationship between disciplinary learning and student learning outcomes

2. The relationship between parental attention and student mathematics learning outcomes

3. The relationship between learning motivation and student learning outcomes

4. Relationship between learning discipline and parents 'attention to students' mathematics learning outcomes

5. Relationship between learning discipline and learning motivation with student mathematics learning outcomes

6. The relationship between parental attention and learning motivation with student mathematics learning outcomes

7. Relationship between the discipline of learning, parental attention and motivation to learn with student mathematics learning outcomes

\section{METHODS}

The type of this research is a type of quantitative research with a population of all class VIII MTs Negeri Sumberagung, Bantul Regency, even semester in the 2015/2016 academic year, amounting to 153 students consisting of 5 classes. Sampling is done by random sampling of classes. The sample of this study amounted to 30 students in class VIII B and class VIII A as a trial class. Data collection techniques used are the test method and questionnaire method. The test is an instrument for measuring data where in response to questions in the instrument, participants are encouraged to show their maximum performance, (Purwanto, 2014: 63 - 64). Tests for variable learning outcomes in mathematics. While the questionnaire for the variables of learning discipline, parental attention, and learning motivation. The questionnaire is a data collection technique that is done by giving a statement to the respondent to answer, (Sugiyono, 2016: 142).

The instruments used are tests and questionnaires. The test is used to obtain data on mathematics learning outcomes on the subject of the circle, while the questionnaire to obtain data on learning discipline, parental attention, and motivation to learn. Before the instrument was tested in the research class so that the test results of the learning outcomes and numerical abilities arranged did not deviate from the material being taught, then a grid was drawn, test questions, questionnaire questions, and review of the items and trial questionnaire. Instruments that have been compiled, then tested in the trial class first, namely class VIII A. Then the test items were analyzed by validity test using product moment formula, different power using the discrimination index formula, and reliability testing using the formula Kuder Richardson-20 (KR -20). Analysis prerequisite test used the normality test, independent test, and linearity test. Data analysis using linear regression analysis and correlation analysis. In addition, a contribution test was carried out to determine the magnitude of the relative contribution and the effective contribution of learning discipline, parental attention, and motivation to learn with mathematics learning outcomes. 


\section{RESULTS AND DISCUSSION}

Based on the research that has been carried out obtained data on learning discipline, parental attention, learning motivation, and learning outcomes of mathematics.

\section{Normality Test}

Based on the normality test that has been done, it was found that the four variables, learning discipline, parental attention, learning motivation, and mathematics learning outcomes were normally distributed. The summary of the results of the normality test can be seen in Table 1 .

Table 1. Normality Test Results

\begin{tabular}{|c|l|c|r|}
\hline No. & Variable & $\chi_{\text {count }}^{2}$ & $\chi_{\text {table }}^{2}$ \\
\hline 1. & Learning discipline $\left(\mathrm{X}_{1}\right)$ & 2,151217985 & 7,8147 \\
\hline 2. & Parents attention $\left(\mathrm{X}_{2}\right)$ & 2,053503264 & 7,8147 \\
\hline 3. & Motivation to learn $\left(\mathrm{X}_{3}\right)$ & 5,517924179 & 7,8147 \\
\hline 4. & $\begin{array}{l}\text { Mathematics Learning } \\
\text { Results }(\mathrm{Y})\end{array}$ & 6,946975143 & 7,8147 \\
\hline
\end{tabular}

\section{Independent Test}

Based on the independent tests that have been done, it was found that the three independent variables, the discipline of learning and the attention of parents, the discipline of learning and the motivation to learn parental attention and motivation to learn, obtained that between variables are mutually independent or mutually independent. The summary of the results of independent tests can be seen in Table 2 .

Table 2. Independent Test Results

\begin{tabular}{|c|l|c|c|}
\hline No. & Variable & $\chi_{\text {count }}^{2}$ & $\chi_{\text {table }}^{2}$ \\
\hline 1 & $X_{1}$ to $X_{2}$ & 29,20633395 & 37,6525 \\
\hline 2 & $X_{1}$ to $X_{3}$ & 32,96765109 & 37,6525 \\
\hline 3 & $X_{2}$ to $X_{3}$ & 21,97790709 & 37,6525 \\
\hline
\end{tabular}

\section{Linearity Test}

Based on the linearity tests that have been done, it was found that between the discipline of learning with mathematics learning outcomes, the attention of parents with mathematics learning outcomes, and motivation to learn with mathematics learning outcomes, there is a linear relationship. The summary of linearity test results can be seen in Table 3 .

Tabel 3. Linearity test results

\begin{tabular}{|l|l|l|l|}
\hline No & Variable & $F_{\text {count }}$ & $F_{\text {tabl }}$ \\
\hline 1 & $\mathrm{X}_{1}$ to $\mathrm{Y}$ & 0,6772673701 & 4,46 \\
\hline 2 & $\mathrm{X}_{2}$ to $\mathrm{Y}$ & 1,952265016 & 3,61 \\
\hline 3 & $\mathrm{X}_{3}$ to $\mathrm{Y}$ & 0,6466532739 & 2,53 \\
\hline
\end{tabular}

\section{Test the Hypothesis}

\section{a. First hypothesis}

Based on the results of a simple correlation analysis of the t-test, the learning discipline correlation coefficient $\left(\mathrm{X}_{1}\right)$ is obtained with the mathematics learning outcomes (Y) of 0,562419102 and result $t_{\text {count }}=3,599242685$ while $t_{\text {tabel }}$ at a significant level $5 \% \mathrm{df}=\mathrm{n}-2=28$, 
with $n=30$ that is equal to 1,7011 . So that $t_{\text {count }}>t_{\text {table, }}$ then the first hypothesis has been tested by refusing $\mathrm{H}_{0,1}$ and accept $\mathrm{H}_{1,1}$ which means that there is a positive and significant relationship between the discipline of learning with the mathematics learning outcomes of class VIII MTs Negeri Sumberagung Bantul Regency Even Semester 2015/2016 Academic Year. Whereas the regression equation is

$$
Y=-8,266310722+0,959015317 X_{1} \text {. }
$$

\section{b. Second hypothesis}

Based on the results of a simple correlation analysis t-test, the correlation coefficient of parental attention $\left(\mathrm{X}_{2}\right)$ is obtained with the mathematics learning outcomes $(\mathrm{Y})$ of 0,3462184605 and result $\mathrm{t}_{\text {count }}=1,952788186$ while $\mathrm{t}_{\text {table }}$ at a significant level $5 \% \mathrm{df}=\mathrm{n}-2=28$, with $\mathrm{n}=30$ that is equal to 1,7011 . So that $t_{\text {count }}>t_{\text {table }}$ then the first hypothesis has been tested by refusing $H_{0,2}$ and accept $H_{1,2}$. This means there is a positive and significant relationship between the attention of parents and the mathematics learning outcomes of class VIII MTs Negeri Sumberagung Bantul Regency Even Semester 2015/2016 Academic Year. Whereas the regression equation is $\hat{Y}=8,775923361+0,7531163435 \mathrm{X}_{2}$.

\section{c. Third hypothesis}

Based on the results of a simple correlation analysis of the t-test, the learning discipline correlation coefficient $\left(\mathrm{X}_{1}\right)$ is obtained with the mathematics learning outcomes (Y) of 0,5075116574 and the result of $t_{\text {count }}=3,116712343$ while $t_{\text {table }}$ at a significant level $5 \% \mathrm{df}=\mathrm{n}-2$ $=28$, with $\mathrm{n}=30$ that is equal to 1,7011 . So that $\mathrm{t}_{\text {count }}>\mathrm{t}_{\text {table }}$, then the first hypothesis has been tested by refusing $\mathrm{H}_{0,3}$ and accept $\mathrm{H}_{1,3}$ which means that there is a positive and significant relationship between motivation to learn and mathematics learning outcomes of class VIII MTs Negeri Sumberagung Bantul Regency Even Semester 2015/2016 Academic Year. Whereas the regression equation is $\hat{Y}=-37,18287781+1,3102291 \mathrm{X}_{3}$.

\section{d. Fourth Hypothesis}

Based on the results of the F-test multiple correlation analysis, the learning discipline correlation coefficient $\left(\mathrm{X}_{1}\right)$ and parents' attention $\left(\mathrm{X}_{2}\right)$ were obtained with the mathematics learning outcomes $(\mathrm{Y})$ of 0,5735563305 and result $\mathrm{F}_{\text {count }}=6,618231547$ while $\mathrm{F}_{\text {table }}$ at a significant level 5\% $\mathrm{df}=\mathrm{n}-2=28$, with $n=30$ that is equal to 3,35 . So that $\mathrm{F}_{\text {count }}>\mathrm{F}_{\text {table }}$, then the first hypothesis has been tested by refusing $\mathrm{H}_{0,4}$ and accept $\mathrm{H}_{1,4}$ which means there is a positive and significant relationship between the discipline of learning and the attention of parents with the mathematics learning outcomes of class VIII MTs Negeri Sumberagung Bantul Regency Even Semester 2015/2016 Academic Year. Whereas the regression equation is $\widehat{Y}=-23,04877797+$ $0,860688204 \mathrm{X}_{1}+0,2718104399 \mathrm{X}_{2}$.

\section{e. Fifth Hypothesis}

Based on the results of the multiple-F correlation analysis, the learning discipline correlation coefficient $\left(\mathrm{X}_{1}\right)$ and learning motivation $\left(\mathrm{X}_{3}\right)$ were obtained with the mathematics learning outcomes $(\mathrm{Y})$ of 0.6449270611 and the results $\mathrm{F}_{\text {count }}=9,613704056$ while $\mathrm{F}_{\text {tabel }}$ at a significant level $5 \% \mathrm{df}=\mathrm{n}-2=28$, with $\mathrm{n}=30$ that is equal to 3,35 . So that $\mathrm{F}_{\text {count }}>\mathrm{F}_{\text {table }}$, then the first hypothesis has been tested by refusing $H_{0,5}$ and accept $H_{1,5}$ which means there is a positive and significant relationship between the discipline of learning and the attention of parents with the mathematics learning outcomes of class VIII MTs Negeri Sumberagung Bantul Regency 
Even Semester 2015/2016 Academic Year. Whereas the regression equation is $\hat{Y}=$ $-23,04877797+0,860688204 X 1+0,2718104399 X_{2}$.

\section{f. Sixth Hypothesis}

Based on the results of the F-test multiple correlation analysis, the correlation of parental attention $\left(\mathrm{X}_{2}\right)$ and learning motivation $\left(\mathrm{X}_{3}\right)$ with mathematical learning outcomes $(\mathrm{Y})$ was obtained at 0.5173934573 and results $\mathrm{F}_{\text {count }}=4,93496664$ while $\mathrm{F}_{\text {table }}$ at a significant level $5 \% \mathrm{df}=\mathrm{n}-2=$ 28 , with $\mathrm{n}=30$ that is equal to 3,35 . So that $\mathrm{F}_{\text {count }}>\mathrm{F}_{\text {table }}$, then the first hypothesis has been tested by refusing $H_{0,6}$ and accept $H_{1,6}$ which means there is a positive and significant relationship between parental attention and learning motivation with the mathematics learning outcomes of class VIII MTs Negeri Sumberagung Bantul Regency Even Semester 2015/2016 Academic Year. Whereas the regression equation is $\hat{Y}=-36,4933508+0,2548216468 \mathrm{X}_{2}+$ $1,048888545 \mathrm{X}_{3}$.

\section{g. Seventh Hypothesis}

Based on the results of the F-test multiple correlation analysis, the learning discipline correlation coefficient $\left(\mathrm{X}_{1}\right)$ was obtained, parental attention $\left(\mathrm{X}_{2}\right)$ and learning motivation $\left(\mathrm{X}_{3}\right)$ with mathematical learning outcomes $(\mathrm{Y})$ of 0.7563508799 and results $\mathrm{F}_{\text {count }}=11,58570847$ while $\mathrm{F}_{\text {table }}$ at a significant level $5 \% \mathrm{df}=\mathrm{n}-\mathrm{m}-1=26$, with $\mathrm{n}=30$ that is equal to 2,98. So that $\mathrm{F}_{\text {count }}>\mathrm{F}_{\text {table, }}$, then the first hypothesis has been tested by refusing $\mathrm{H}_{0,7}$ and accept $\mathrm{H}_{1,7}$ which means there is a positive and significant relationship between the discipline of learning, parental attention and learning motivation with the mathematics learning outcomes of class VIII MTs Negeri Sumberagung Bantul Regency Even Semester 2015/2016 Academic Year. Whereas the regression equation

$$
\widehat{Y}=-177,18333333+1,347711321 X_{1}+0,5600427032 X_{2}+0,164197423 X_{3}
$$

\section{Relative Contributions and Effective Donations}

The relative contribution size and the amount of effective contribution for each variable X1, $\mathrm{X} 2$, and $\mathrm{X} 3$ with $\mathrm{Y}$ variables can be seen in Table 4 .

Table 4. Relative Donations and Effective Donations

\begin{tabular}{|l|c|c|}
\hline Variable & Relative Donations & Effective Donations \\
\hline $\mathrm{X}_{1}$ & $78,20280735 \%$ & $18,78586019 \%$ \\
\hline $\mathrm{X} 2$ & $15,58162972 \%$ & $15,58162972 \%$ \\
\hline $\mathrm{X}_{3}$ & $6,215562936 \%$ & $6,215562936 \%$ \\
\hline Total & $100 \%$ & $40,58305285 \%$ \\
\hline
\end{tabular}

\section{CONCLUSION}

Based on the results of research and discussion, conclusions can be drawn, namely:

1. There is a positive and significant relationship between the discipline of learning with the mathematics learning outcomes of class VIII MTs Negeri Sumberagung Bantul Regency even semester 2015/2016 Academic Year.

2. There is a positive and significant relationship between the attention of parents with the mathematics learning outcomes of class VIII MTs Negeri Sumberagung, Bantul Regency even semester 2015/2016 Academic Year.

3. There is a positive and significant relationship between learning motivation and learning outcomes of mathematics in grade VIII students of Sumberagung, MTs Negeri Sumberagung, Bantul Regency, even semester 2015/2016 Academic Year. 
4. There is a positive and significant relationship between the discipline of learning and the attention of parents with the mathematics learning outcomes of class VIII MTs Negeri Sumberagung, Bantul Regency even semester 2015/2016 Academic Year.

5. There is a positive and significant relationship between learning discipline and learning motivation with the mathematics learning outcomes of eighth-grade students of MTs Negeri Sumberagung Bantul Regency, even semester 2015/2016 Academic Year.

6. There is a positive and significant relationship between parental attention and learning motivation with the mathematics learning outcomes of class VIII MTs Negeri Sumberagung Bantul Regency even semester 2015/2016 Academic Year.

7. There is a positive and significant relationship between the discipline of learning, parental attention, and learning motivation with the mathematics learning outcomes of class VIII students of MTs Negeri Sumberagung, Bantul Regency, even semester 2015/2016 Academic Year.

\section{REFERENCES}

Bimo Walgito. (2010). Pengantar Psikologi Umum. Yogyakarta: C.V Andi Offset.

Erman Suherman, dkk. (2003). Strategi Pembelajaran Matematika Kontemporer. Bandung: UPI.

Purwanto. (2014). Evaluasi Hasil Belajar. Yogyakarta: Pustaka Pelajar.

Slameto. (2013). Belajar dan Faktor-faktor Yang Mempengaruhinya. Jakarta: PT Rineke Cipta.

Sugiyono. (2010). Metode Penelitian Pendidikan. Bandung: Alfabeta.

Syaiful Bahri Djamarah. (2014). Pola Asuh Orang Tua dan Komunikasi dalam Keluarga. Jakarta: PT Rineka Cipta.

. (2011). Psikologi Belajar. Jakarta: PT Rineka Cipta.

Wasty Soemanto. (2012). Psikologi Pendidikan. Jakarta: Rineka Cipta. 